\title{
Micronodular lung lesions in an HIV positive patient - dilemmas in differential diagnosis
}

\author{
Simona Claudia Cambrea ${ }^{1,2^{*}}$, Ghiulendan Resul ${ }^{1}$, Eugenia Basca ${ }^{1}$, Elena Dantes ${ }^{2}$, Stela Halichidis ${ }^{1,2}$ \\ From The 9th Edition of the Scientific Days of the National Institute for Infectious Diseases Prof Dr Matei Bals \\ Bucharest, Romania. 23-25 October 2013
}

\begin{abstract}
Background
In HIV positive patients from countries with a high burden of tuberculosis (TB), patients with lung cancer are often misdiagnosed as pulmonary tuberculosis, leading to delay in the correct diagnosis as well as exposure to inappropriate medication. Even though there are many similarities between the two diseases (involvement of the lung parenchyma and similar symptoms), there are also many differences between them like different etiologies, different consequences, and altogether different management.
\end{abstract}

\section{Case report}

We performed a retrospective study on the hospitalizations and ambulatory records of an HIV positive patient. We present the case of a 61 year-old male patient, who was diagnosed with HIV infection in July 1996, acquired by heterosexual route. He used to be a smoker, 10 cigarettes/day, for the last 25 years, even though in the last 5 years he had quitted smoking. He was compliant for the HIV treatment, with a good evolution. In December 2010 he was diagnosed with pulmonary TB and he received specific treatment. After 4 months of antituberculous treatment the patient became asthenic, febrile, with productive cough, and weight lost. The radiologic (chest X-ray and CT) evolution was unfavorable. The suspicion of pulmonary neoplasm rose three weeks prior to his death. At the necropsy, macroscopic lung examination was very confusing between pulmonary TB and lung neoplasm, with a micronodular pattern similar with milliary TB. Histopathological examination evidenced a lung adenocarcinoma.

\section{Conclusion}

A wrong or missed diagnosis of lung cancer by clinicians can lead to delays in treatment, wrong treatments,

\footnotetext{
* Correspondence: claudia_cambrea@hotmail.com

${ }^{1}$ Clinical Infectious Diseases Hospital of Constanța, Romania

Full list of author information is available at the end of the article
}

and finally death of the patient. In cases in which differential diagnosis is difficult to establish, histopathological examination establishes the final diagnosis.

\section{Authors' details}

${ }^{1}$ Clinical Infectious Diseases Hospital of Constanța, Romania. ${ }^{2}$ Faculty of Medicine, "Ovidius" University, Constanta, Romania.

Published: 16 December 2013

doi:10.1186/1471-2334-13-S1-P14

Cite this article as: Cambrea et al: Micronodular lung lesions in an HIV positive patient - dilemmas in differential diagnosis. BMC Infectious Diseases 2013 13(Suppl 1):P14.

Submit your next manuscript to BioMed Central and take full advantage of:

- Convenient online submission

- Thorough peer review

- No space constraints or color figure charges

- Immediate publication on acceptance

- Inclusion in PubMed, CAS, Scopus and Google Scholar

- Research which is freely available for redistribution

Submit your manuscript at www.biomedcentral.com/submit
() Biomed Central

\section{Ciomed Central}

